DOI: 10.12731/2658-6649-2021-13-4-224-237

UDC 574.24

\title{
ASSESSMENT OF THE LEVEL OF STRESS ON PLANTS OF WESTERN SIBERIAN RAISED BOGS BY THE METHOD OF FRACTAL ANALYSIS
}

\section{V.B. Ivanov, A.V.Scherbakov}

Sufficient evidence has been collected that alternative biological and ecological processes may occur in individual plant specimens that dwell in environmentally equivalent habitats. Environmental stress triggers individual, specimen-specific adaptive response. The paper shows how fractal analysis can be used to study the degree of stress that plants in different habitats and environmental factor combinations are exposed to.

Keywords: fractal analysis; habitat; stress; morphological and physiological parameters

For citation. Ivanov V.B., Scherbakov A.V. Assessment of the Level of Stress on Plants of Western Siberian Raised Bogs by the Method of Fractal Analysis. Siberian Journal of Life Sciences and Agriculture, 2021, vol. 13, no. 4, pp. 224-XX. DOI: 10.12731/2658-6649-2021-13-4-224-237

\section{ОЦЕНКА УРОВНЯ СТРЕССОВОЙ НАГРУЗКИ НА РАСТЕНИЯ ВЕРХОВЫХ БОЛОТ ЗАПАДНОЙ СИБИРИ МЕТОДОМ ФРАКТАЛЬНОГО АНАЛИЗА}

\author{
В.Б. Иванов, А.В. Щербаков
}

В настоящее время накопилось достаточно сведений, что в экологически эквивалентных условиях средь обитания могут реализоваться альтернативные биологические и экологические процеессы у индивидуальных образиов растений. Давление окружающей среды на растения, способствует запуску индивидуальных, отличных от других растений данного сообщества, ответных адаптивных механизмов. В статье показана возможность применения фрактального анализа для изучения степени стрессовой нагрузки у растений в различных местообитаниях и комбинациях факторов внешней среды. 
Ключевые слова: фрактальный анализ; условия обитания; стресс; морфофизиологические параметры

Для цитирования. Иванов В.Б., Щербаков А.В. Оиенка уровня стрессовой нагрузки на растения верховых болот Западной Сибири методом фрактального анализа // Siberian Journal of Life Sciences and Agriculture. 2021. T. 13, № 4. C. 224-XX. DOI: 10.12731/2658-6649-2021-13-4-224-237

\section{Introduction}

Individual environmental factors vary substantially, which is typical of natural plant habitats $[1,2,12,8]$. Another important factor of such natural habitats is that they are dynamic, which causes the ubiquitous presence of various stressors [20, 21]. Lack of mineral nutrients, suboptimal water access and temperatures, and fierce competition are but a few of the many common natural stressors $[3,6,15,22]$. Under such conditions, plants develop an extremely complex and plastic pattern of adaptive responses; these processes in individual plant specimens can be tracked by a broad spectrum of direct and recalculated morphological and physiological indicators $[9,28,36]$.

Several papers have shown that in order to adapt to such unpredictable habitats, plants apply a multiplicity of adaptive responses, which makes them radically different from animals $[5,13,14,16,17,18,38]$. The principle is essential as follows: when exposed to this or that stress, a plant will trigger as many protective mechanisms as their resources allow $[23,19]$. The intensity ratio of these mechanisms in individual plant specimens may vary on a daily basis whether in a laboratory setting or in field. In terms of the quantity and quality of its physiological mechanisms, a single plant may differ not only from its neighbors, but also from its former self from a day or a few days ago [11, 37, 39].

This is why the specimen-specific indicators and the general pattern of correlations in the environmental parameters vary so greatly. Correlations between plant indicators show a high degree of plasticity, which makes it difficult to estimate the influence of individual factors and the general stress that plants in this or that habitat are exposed to. Apparently, more intense stress is associated with lower resources available to plant defenses, which means plants need to use less defenses. This fully applies to plants in the harsh wilds of Western Siberia $[4,24,25,26,28,29,31,32,33]$.

Therefore, plants may be expected to have more similar behavior when under severe stress, which can be shown by a variety of mathematical methods. This is the idea behind this research. To date, science lacks a simple and versatile stress assessment method applicable to plants in natural habitats. 


\section{Materials and Methods}

The fractal analysis finds ever greater use in biology and ecology. The general principles and applicability of fractal analysis to the ecological physiology of plants consist in the following. A multi-level object that features self-similarity across its levels, or a process that has self-similarity across its timespan, can be considered of fractal nature [7, 27, 31].

The fractal analysis classifies any multi-component system into one of the three categories:

- regular objects;

- fractal objects;

- predominantly chaotic objects.

Fractal analysis methods described in the literature and adapted herein apply to any array of specimen-specific data. This applies to both plants and to soil sampled in plant habitats. The fractal analysis procedure is outlined in Table 1 .

Steps of fractal analysis

Table 1 .

\begin{tabular}{|c|c|c|}
\hline Step & Actions & Criteria and results \\
\hline Sampling & $\begin{array}{l}\text { This step produces a matrix sized } \\
10^{*} 10 \text { as a minimum; the matrix con- } \\
\text { tains the inputs (specimen-specific } \\
\text { indicators). Columns are for the indica- } \\
\text { tors, and lines are for their values. After } \\
\text { lines with specimen-specific values, } \\
\text { there go lines that sum these values and } \\
\text { scale them by an increasing value (by } \\
2,3,4 \text {, and 5). The lowest value is for } \\
\text { the totals of individual cells. }\end{array}$ & $\begin{array}{l}\text { There must be at least } 10 \text { indi- } \\
\text { cators. The number of objects } \\
\text { for analysis must be composite } \\
(10,12,15,16 \text {, etc. })\end{array}$ \\
\hline $\begin{array}{l}\text { Determine } \\
\mathrm{N} \text { (the } \\
\text { scale) }\end{array}$ & $\begin{array}{l}\text { The scale varies from } 1 \text { (singular } \\
\text { specimens) to a maximum equal to the } \\
\text { total number of tested specimens, N. }\end{array}$ & $\begin{array}{l}\mathrm{N} \text { is essentially the maximum } \\
\text { total number of tested individ- } \\
\text { ual specimens. }\end{array}$ \\
\hline $\begin{array}{l}\text { Find } n_{i} \text {, the } \\
\text { contribution } \\
\text { of each } \\
\text { value to the } \\
\text { total of each } \\
\text { parameter. }\end{array}$ & $\begin{array}{l}\text { This is a conventional ranking by } \\
\text { variables. For each parameter, divide } \\
\text { the value of each cell by the total in } \\
\text { the bottom line. This will produce } \\
\text { relative values for each parameter. }\end{array}$ & $\begin{array}{l}\text { Cells should therefore total } 1 \\
\text { in the bottom line. Other cells } \\
\text { must be less than } 1 \text { and in- } \\
\text { crease proportionally as more } \\
\text { and more cells are summed up } \\
\text { until the value reaches } 1\end{array}$ \\
\hline $\begin{array}{l}\text { Find q (the } \\
\text { scaling } \\
\text { range) }\end{array}$ & $\begin{array}{l}\text { A fractal object must feature } \\
\text { self-similarity across a wide range of } \\
\text { scales. The range is set by the values } \\
\text { of q. }\end{array}$ & $\begin{array}{l}\text { In practice, a q range from }-5 \text { to } \\
5 \text { with increments of } 0.1 \text { to } 0.5 \text { is } \\
\text { sufficient. The increment can be } \\
\text { reduced for a greater resolution. }\end{array}$ \\
\hline
\end{tabular}


End of a Table 1.

\begin{tabular}{|l|l|l|}
\hline $\begin{array}{l}\text { Calculate } \\
\text { the value of } \\
\text { distribution } \\
\text { moments Mq }\end{array}$ & $\begin{array}{l}\text { 1. For each q, raise the values of the } \\
\text { matrix to the power of q. } \\
\text { 2. In each of the matrices, find the to- } \\
\text { tals of each horizontal row in each line. }\end{array}$ & $\begin{array}{l}\text { The result is the scaling of } \\
\text { distribution moments Mq }\end{array}$ \\
\hline $\begin{array}{l}\text { Scaling of } \\
\text { the distri- } \\
\text { bution mo- } \\
\text { ments Mq }\end{array}$ & $\begin{array}{l}\text { Fundamental for fractal analysis is } \\
\text { the fact that Mq is a power function } \\
\text { of N. This can be proven by calcu- } \\
\text { lating the coefficients of correlation } \\
\text { between the logarithms of these pa- } \\
\text { rameters for the given q. }\end{array}$ & $\begin{array}{l}\text { logMq is in a significant cor- } \\
\text { relation with logN; this is the } \\
\text { fundamental sign of self-sim- } \\
\text { ilarity in the tested object, } \\
\text { therefore of its potential fractal } \\
\text { nature. }\end{array}$ \\
\hline
\end{tabular}

Self-similarity is considered proven if $\log \mathrm{Mq}$ is in significant correlation with $\log \mathrm{N}$ across the $\mathrm{q}$ range. This is the primary condition of being in line with the principles of fractal formalism.

The practice of fractal analysis of plant and soil parameters has shown that the coefficient of significant $(\mathrm{p} \leq 0.05)$ correlation between $\log \mathrm{Mq}$ and $\log \mathrm{N}$ may vary in a range that depends on the object under analysis. A coefficient equal to 1 in absolute value means that the input array contains indicators of identical elements and represents a regular object. If the coefficient deviates from -1 to 1 whilst still being significant, it signifies a greater diversity in specimen-specific indicators.

\section{Results and Discussions}

Studies carried out by the authors hereof show that indeed, habitat and in particular the mineral nutrition it provides is of utmost importance for diversifying the indicators. Stress that Oxycoccus palustris Pers., Chamaedaphne calyculata (L.) Moench., Andromeda polifolia L. was exposed to was measured by fractal analysis of plant and soil parameters in a control field and an experimental field. The control field was the tested plants' natural habitat. The experimental field was natural habitat with a single application of Nitroammophosca, see Table 2.

Table 2.

Fractal analysis of the indicators of Oxycoccus palustris Pers., Chamaedaphne calyculáta (L.) Moench., Andromeda polifolia L. and soil in Western Siberia

\begin{tabular}{|c|c|l|c|}
\hline No. & $\begin{array}{c}\text { Object, } \\
\text { year, site }\end{array}$ & $\begin{array}{c}\text { Parameters used } \\
\text { in fractal analysis }\end{array}$ & $\begin{array}{c}\text { Average absolute value of the log- } \\
\text { Mq-logN correlation coefficient }\end{array}$ \\
\hline 1 & $\begin{array}{c}\text { Cranberry, } \\
2014, \text { control }\end{array}$ & $\begin{array}{l}\text { Morphological and weight parame- } \\
\text { ters, total flavonoid content }\end{array}$ & 0.922 \\
\hline 2 & $\begin{array}{c}\text { Cranberry, } \\
2014, \text { fertilized }\end{array}$ & $\begin{array}{l}\text { Morphological and weight parame- } \\
\text { ters, total flavonoid content }\end{array}$ & 0.915 \\
\hline 3 & $\begin{array}{c}\text { Myrtle, 2014, } \\
\text { control }\end{array}$ & $\begin{array}{l}\text { Morphological and weight parame- } \\
\text { ters, total flavonoid content }\end{array}$ & 0.922 \\
\hline
\end{tabular}


End of a Table 2.

\begin{tabular}{|c|c|l|c|}
\hline 4 & $\begin{array}{c}\text { Myrtle, 2014, } \\
\text { fertilized }\end{array}$ & $\begin{array}{l}\text { Morphological and weight parame- } \\
\text { ters, total flavonoid content }\end{array}$ & 0.995 \\
\hline 5 & $\begin{array}{c}\text { Bog rosemary, } \\
2014, \text { control }\end{array}$ & $\begin{array}{l}\text { Morphological and weight parame- } \\
\text { ters, total flavonoid content }\end{array}$ & 0.922 \\
\hline 6 & $\begin{array}{c}\text { Bog rosemary, } \\
2014, \text { fertilized }\end{array}$ & $\begin{array}{l}\text { Morphological and weight parame- } \\
\text { ters, total flavonoid content }\end{array}$ & 0.920 \\
\hline & $\begin{array}{c}\text { Soil, 2014, } \\
\text { control }\end{array}$ & $\begin{array}{l}\text { Concentrations of } \mathrm{P}, \mathrm{N}, \mathrm{Cd}, \mathrm{Pb}, \mathrm{Cu}, \\
\text { Zn, Fe, Mn }\end{array}$ & 0.88 \\
\hline $\begin{array}{c}\text { Soil, 2014, fer- } \\
\text { tilized }\end{array}$ & $\begin{array}{l}\text { Concentrations of } \mathrm{P}, \mathrm{N}, \mathrm{Cd}, \mathrm{Pb}, \mathrm{Cu}, \\
\mathrm{Zn}, \mathrm{Fe}, \mathrm{Mn}\end{array}$ & 0.922 \\
\hline
\end{tabular}

\section{Notes:}

1. Nitroammophosca, an N/P/K fertilizer, was applied once early in summer vegetation at a dose of $16 \mathrm{~kg} / \mathrm{ha}$.

2. All the correlation coefficients shown in the table are significant at $\mathrm{p} \leq 0.05$

3. A total of 27 plant indicators and 10 soil indicators were tested by fractal analysis.

As shown in Table 2, two of the three tested species (Oxycoccus palustris Pers., Andromeda polifolia L.) had a slight reduction in their $\log \mathrm{Mq}-\log \mathrm{N}$ correlation coefficient as a result of applying the fertilizer in early vegetation; thus, the difference between the specimen-specific morphological and physiological indicators increased. The authors hereof believe this could indicate a slight improvement in their habitats.

Therefore, it might be safe to say that the $\log \mathrm{Mq}-\log \mathrm{N}$ correlation coefficient for different species in their natural habitats can be used as a universal stress indicator.

This study produced a general algorithm of how to use fractal analysis to assess the condition of plants exposed to a varying degree of stress. Fractal analysis-based testing for stress involves these steps:

1. Collect specimen-specific indicator values.

2. Add the input to the unified matrix.

3. Find (if necessary, adjust) the scaling range q.

4. Run the fractal analysis.

5. Find the $\log \mathrm{Mq}-\log \mathrm{N}$ correlation coefficients.

6. Compare the coefficients against the reference, i.e., against the values typical of regular objects (-1 for negative q, 1 for positive q).

7. Find the deviation of the correlation coefficient from the reference for each q.

8. Assess the stress. 


\section{Conclusions}

The proposed plant stress assessment technique can use any data specific to a single plant specimen, whether it is growth or morphological indicators, the concentrations of individual metabolites including the secondary ones, or local readings of the habitats, be it soil, atmospheric, or hydrological readings. The key requirement is to avoid zeroes in data as much as possible, as such data might skew the calculations and result in misevaluation of stress. The method requires a minimum data array of $10 * 10$ (10 plant specimens and 10 indicators). Stress calculations involve Excel and Statistica.

\section{Acknowledgments}

The work was supported by the grant from the Russian Foundation for Basic Research (RFBR) 18-44-860006 r_a.

\section{References}

1. Aleksandrova V.V., Ivanov V.B., Vojtova V.A. Siberian Journal of Life Sciences and Agriculture, 2020, vol. 12 (1), pp. 71-78. https://doi.org/10.12731/26586649-2020-12-1-71-78

2. Aleksandrova V.V., Ivanov V.B., Ivanov N.A., Marach V.S. Vmire nauchnyh otkrytij [Siberian Journal of Life Sciences and Agriculture], 2017. vol. 9. № 1-2. pp. 36-41.

3. Bever J.D., Dickie I.A., Facelli E., Facelli J.M., Klironomos J., Moora M, ... Rillig M.C. Rooting theories of plant community ecology in microbial interactions. Trends in Ecology and Evolution, 2010, vol. 25, no. 8, pp. 468-478. https://doi.org/10.1016/j.tree.2010.05.004

4. Volkov I.M., Ryahin M.S., Belousov S.N., Aleksandrova V.V., Ivanov V.B. Neftyanoe hozyajstvo [Oil Industry]. 2018, vol. 2, pp. 109-112. https://doi. org/10.24887/0028-2448-2018-2-109-112

5. Bundy J.G., Davey M.P., Viant M.R. Environmental metabolomics: a critical review and future perspectives. Metabolomics, 2009, vol. 5, no. 1, pp. 3-21. http://dx.doi.org/10.1007/s11306-008-0152-0

6. Gaston K.J., Choun S.L. Neutrality and niche. Functional ecology, 2005, vol. 19, no. 1, pp. 1-6. https://doi.org/10.1111/j.0269-8463.2005.00948.x

7. Gelashvili D.B., Iudin D.I., Rosenberg G.S., Yakimov V.N., Solntsev L.A. Fraktaly $i$ mul'tifraktaly $v$ bioekologii [Fractals and multifractals in bioecology]. Nizhny Novgorod: Nizhny Novgorod University, 2013, 370 p.

8. Ivanov V.B., Alexandrova V.V., Usmanov I.Y., Yumagulova E.R., Chibrikov O.V., Ivanov N.A., Shcherbakov A.V. Vegetos: An International Journal of Plant Research, 2016, vol. 29, no. 2, pp. 47-50. https://doi.org/10.5958/22294473.2016.00018.5 
9. Ivanov V., Shcherbakov A. Modern Phytomorphology, 2021, vol. 15, pp. 56-61. https://www.phytomorphology.com/articles/enzymes-of-flavonoid-biosynthesis-as-a-reason-for-the-polyvariant-nature-of-their-accumulation.pdf

10. Ivanov V.B., Shcherbakov A.V., Gonhar I.G., Ivanova A.V., Usmanov I.Yu. International Journal of Advanced Biotechnology and Research (IJABR), 2019, vol. 10, no. 2, pp. 456-464. https://bipublication.com/files/ijabr2019263Ivanov.pdf

11. Ivanov V., Shcherbakov A., Usmanov I. Modern Phytomorphology, 2021, vol. 15, pp. 48-50. https://www.phytomorphology.com/articles/bifurcations-and-neutrality-in-the-biosynthesis-of-plant-flavonoids.pdf

12. Ivanov V.B., Dolgih A.M., Loginov A.M., Ivanova L.G. V mire nauchnyh otkrytij [Siberian Journal of Life Sciences and Agriculture], 2018. vol. 10. № 3-2. pp. 28-36.

13. Kimura M. The Neutral Theory of Molecular Evolution. Cambridge: Cambridge University Press, 1983. https://doi.org/10.1017/CBO9780511623486

14. Lambers H., Chapin F.S., Pons T.L. Plant physiological ecology. Springer, 2008, 605 p. https://www.springer.com/gp/book/9781493937059

15. Mavletova-Chistyakova M.V., Shcherbakov A.V., Ivanov V.B., Yumagulova E.R., Usmanov I.Yu. Vestnik Nizhnevartovskogo gosudarstvennogo universiteta [Bulletin of Nizhnevartovsk State Humanitarian University]. 2017, vol. 4, pp. 124-133. https://vestnik.nvsu.ru/2311-1402/article/view/49618

16. Mandelbrot B.B. The fractal geometry of nature. New York: Freeman, 1982, $468 \mathrm{p}$.

17. Mierziak J., Kostyn K., Kulma A. Flavonoids as Important Molecules of Plant Interactions with the Environment. Molecules. 2014, vol. 19, no. 10, pp. 1624016265. https://doi.org/10.3390/molecules 191016240

18. McGill B.J. Towards a unification on unified theories of biodiversity. Ecology Letters, 2010, vol. 13, no. 5, pp. 627-642. https://doi.org/10.1111/j.14610248.2010.01449.x

19. Petrussa E., Braidot E., Zancani M., Peresson C., Bartolini A., Patui S., Vianello A. Plant flavonoids-biosynthesis, transport and involvement in stress responses. Int. J. Mol. Sci, 2013, vol. 14, no. 7, pp. 14950-14973. https://doi.org/10.3390/ ijms140714950

20. Rosenberg G.S. Modeli v fitocenologii. Moscow: USSR: Publishing House Nau$\mathrm{ka}, 1984,240 \mathrm{p}$.

21. Rosenberg G.S. Introduction to Theoretical Ecology / In two volumes; 2nd ed., revised and expanded. Togliatti: Cassandra, 2013. V. 1. 565 p. V. 2. 445 p.

22. Tilman D. Niche tradeoffs, neutrality, and community structure: A stochastic theory of resource competition, invasion and community assembly. Presiding 
of the National Academy of Science (PNAS), 2004, vol. 101, no. 30, pp. 10854 10861. https://doi.org/10.1073/pnas.0403458101

23. Usmanov I.Yu., Shcherbakov A.V., Mavletova M.V., Yumagulova E.R., Ivanov V.B., Aleksandrova V.V. Izvestiya Samarskogo nauchnogo centra Rossijskoj akademii nauk [Bulletin of the Samara Scientific Center of the Russian Academy of Sciences]. 2016, vol. 18 (2-2), pp. 525-529. http://www.ssc.smr.ru/media/ journals/izvestia/2016/2016_2_525_529.pdf

24. Usmanov I.Yu., Yumagulova E.R., Ivanov V.B., Korkina E.A., Shcherbakov A.V., Ivanov N.A., Ryabuha A.V. Vestnik Nizhnevartovskogo gosudarstvennogo universiteta [Bulletin of Nizhnevartovsk State Humanitarian University], 2016, vol. 2, pp. 87-94. https://vestnik.nvsu.ru/2311-1402/article/view/49497

25. Usmanov I.Yu., Ivanov V.B., Ivanov N.A. Ekologicheskie problemy bassejnov krupnyh rek - 6: Materialy mezhdunarodnoj konferencii [Environmental problems of large river basins - 6: Materials of the international conference]. Tol'yatti: Anna, 2018, pp. 303-305.

26. Usmanov I.Yu., Ovechkina E.S., Yumagulova E.R., Ivanov V.B., Shcherbakov A.V., Shayahmetova R.I. Vestnik Nizhnevartovskogo gosudarstvennogo universiteta [Bulletin of Nizhnevartovsk State Humanitarian University], 2015, no. 1, pp. 79-86. https://vestnik.nvsu.ru/2311-1402/article/view/49407

27. Usmanov I.Yu., Shcherbakov A.V., Ivanov V.B., Yumagulova E.R. Trudy IX S"ezda obshchestva fiziologov rastenij Rossii «Fiziologiya rastenij - osnova sozdaniya rastenij budushchego» [IX Congress of the Society of Plant Physiologists of Russia "Plant Physiology - the basis for the creation of plants of the future"]. Kazan': Izdatel'stvo Kazanskogo universiteta, 2019, 446 p.

28. Usmanov I.YU., Shcherbakov A.V., Yumagulova E.R., Ivanov V.B. Ekologiya i evolyuciya: novye gorizonty. Materialy Mezhdunarodnogo simpoziuma, posvyashchennogo 100-letiyu akademika S.S. Shvarca. Institut ekologii rastenij i zhivotnyh [Ecology and Evolution: New Horizons. Materials of the International Symposium dedicated to the 100th anniversary of Academician S.S. Schwartz]. UrO RAN, 2019, pp. 288-289.

29. Usmanov I.Yu., Yumagulova E.R., Aleksandrova V.V., Gonchar I.G., Shcherbakov A.V., Ivanov V.B. Vestnik Nizhnevartovskogo gosudarstvennogo universiteta [Bulletin of Nizhnevartovsk State Humanitarian University], 2019, no. 2, pp. 59-71. https://doi.org/10.36906/2311-4444/19-2/08

30. Usmanov I.Yu., Yumagulova E.R., Ivanov V.B., Aleksandrova V.V., Ivanov N.A., Schaichmetova R.I., Scherbakov A.V., Mavletova-Chistuakova M.V. Vegetos: An International Journal of Plant Research, 2017, vol. 30, no. 4, pp. 81-85. https://doi.org/10.5958/2229-4473.2017.00195.1 
31. Usmanov I., Ivanov V., Shcherbakov A. Modern Phytomorphology, 2020, vol. 14, pp. 77-84. https://www.phytomorphology.com/articles/system-for-ecological-regulation-of-the-biosynthesis-of-flavonoids-as-a-strange-attractor.pdf

32. Usmanov I.Yu., Yumagulova E.R., Aleksandrova V.V., Ivanov S.P., Shcherbakov A.V., Ivanov V.B., Gonchar I.G. Modern Phytomorphology, 2019, vol. 13, pp. 35-40. https://nvsu.ru/ru/scientific_laboratories/396/55.pdf

33. Usmanov I.Yu., Ivanov V.B., Abdrakhimova G.S., Shcherbakov A.V., Yumagulova E.R., Aleksandrova V.V. International Journal of Advanced Biotechnology and Research, 2019, vol. 10, no. 2, pp. 369-376. https://www.bipublication.com/ files/ijabr2019252Usmanov.pdf

34. Usmanov I.Yu., Yumagulova E.R., Ovechkina E.S., Ivanov V.B., Aleksandrova V.V., Ivanov N.A., Shcherbakov A.B. Vegetos: An International Journal of Plant Research, 2016, vol. 29, no. 1, pp. 1-3. https://doi.org/10.5958/2229-4473.2016.00002.1

35. Usmanov I., Shcherbakov A., Ivanov V., Ivanov S., Gonchar I. Modern Phytomorphology, 2020, vol. 14, pp. 13-19. https://doi.org/10.5281/zenodo.4453866

36. Usmanov I.Yu., Scherbakov A.V., Ivanov V.B., Ivanova A.V. Fractal Nature of Multidimensional Ecological Niche: Real Habitats in South Trans-Urals / S.G. Maximova, R.I. Raikin, M.M. Silantyeva, \& A.A. Chibilyov (Eds.), Advances in Natural, Human-Made, and Coupled Human-Natural Systems. Cham, Switzerland: Springer, 2021.

37. Harborne J.B. The flavonoids: advances in research since. Springer, 1980. https://www.springer.com/gp/book/9780412287701

38. Hubbell S.P. Neutral theory and the evolution of ecological equivalence. Ecology, 2006, vol. 87, no. 6, pp. 1387-1398. https://doi. org/10.1890/0012-9658(2006)87[1387:ntateo]2.0.co;2

39. Scherbakov A.V., Ivanov V.B., Ivanova A.V., Usmanov I.Y. The Equifinal Achievement of the Total Antioxidant Activity of Flavonoids by Plants in Various Habitats. IOP Conference Series: Earth and Environmental Science, 2021, vol. 670(1). https://doi.org/10.1088/1755-1315/670/1/012018

\section{Список литературы}

1. Александрова В.В., Иванов В.Б., Войтова В.А. Анализ корреляционной зависимости результатов токсикологических экспериментов от уровня $\mathrm{pH}$ воды // Siberian Journal of Life Sciences and Agriculture. 2020. T. 12, № 1. C. 71-78. https://doi.org/10.12731/2658-6649-2020-12-1-71-78

2. Александрова В.В., Иванов В.Б., Иванов Н.А., Марач В.С. Оценка качества воды озер нижневартовского района по критерию выживаемости Daphnia Magna // В мире научных открытий. 2017. Т. 9, № 1-2. С. 36-41. 
3. Bever J.D., Dickie I.A., Facelli E., Facelli J.M., Klironomos J., Moora M, ... Rillig M.C. Rooting theories of plant community ecology in microbial interactions // Trends in Ecology and Evolution, 2010, vol. 25, no. 8, pp. 468-478. https://doi.org/10.1016/j.tree.2010.05.004

4. Волков И.М., Ряхин М.С., Белоусов С.Н., Александрова В.В., Иванов В.Б. Обеспечение экологической безопасности проектных решений на территории лицензионных участков недропользователей с применением наилучших доступных технологий // Нефтяное хозяйство. 2018. № 2. С. 109-112. https://doi.org/10.24887/0028-2448-2018-2-109-112

5. Bundy J.G., Davey M.P., Viant M.R. Environmental metabolomics: a critical review and future perspectives // Metabolomics, 2009, vol. 5, no. 1, pp. 3-21. http://dx.doi.org/10.1007/s11306-008-0152-0

6. Gaston K.J., Choun S.L. Neutrality and niche // Functional ecology, 2005, vol. 19, no. 1, pp. 1-6. https://doi.org/10.1111/j.0269-8463.2005.00948.x

7. Гелашвили Д.В., Иудин Д.И., Розенберг Г.С., Якимов В.Н. Солнцев Л.А. Фракталы и мультифракталы в биоэкологии. Нижний Новгород: Нижегородский университет, 2013. 370 с.

8. Ivanov V.B., Alexandrova V.V., Usmanov I.Y., Yumagulova E.R., Chibrikov O.V., Ivanov N.A., Shcherbakov A.V. Comparative evaluation of migrating anthropogenic impurities in ecosystems of the Middle Ob Region through Bioindication and Chemical analysis // Vegetos: An International Journal of Plant Research, 2016, vol. 29, no. 2, pp. 47-50. https://doi.org/10.5958/22294473.2016.00018.5

9. Ivanov V., Shcherbakov A. Enzymes of flavonoid biosynthesis as a reason for the polyvariant nature of their accumulation // Modern Phytomorphology, 2021, vol. 15, pp. 56-61. https://www.phytomorphology.com/articles/enzymes-of-flavonoid-biosynthesis-as-a-reason-for-the-polyvariant-nature-of-their-accumulation.pdf

10. Ivanov V.B., Shcherbakov A.V., Gonhar I.G., Ivanova A.V., Usmanov I.Yu. Using the Principles of Fractal Analysis for Description of Plant Flavonids Metabolism // International Journal of Advanced Biotechnology and Research (IJABR), 2019, vol. 10, no. 2, pp. 456-464. https://bipublication.com/files/ ijabr2019263Ivanov.pdf

11. Ivanov V., Shcherbakov A., Usmanov I. Bifurcations and neutrality in the biosynthesis of plant flavonoids // Modern Phytomorphology, 2021, vol. 15, pp. 48-50. https://www.phytomorphology.com/articles/bifurcations-and-neutrality-in-the-biosynthesis-of-plant-flavonoids.pdf

12. Иванов В.Б., Долгих А.М., Логинов А.М., Иванова Л.Г. Проблема добычи углеводородов и рекультивации нефтезагрязненных земель на территории 
Ханты-Мансийского автономного округа-Югры // В мире научных открытий. 2018. Т. 10, № 3-2. С. 28-36.

13. Kimura M. The Neutral Theory of Molecular Evolution. Cambridge: Cambridge University Press, 1983. https://doi.org/10.1017/CBO9780511623486

14. Lambers H., Chapin F.S., Pons T.L. Plant physiological ecology. Springer, 2008, 605 p. https://www.springer.com/gp/book/9781493937059

15. Мавлетова-Чистякова М.В., Щербаков А.В., Иванов В.Б., Юмагулова Э.Р., Усманов И.Ю. Пульсирующая мозаичность параметров почв Южного Зауралья // Вестник Нижневартовского государственного университета. 2017. № 4. C. 124-133. https://vestnik.nvsu.ru/2311-1402/article/view/49618/ru_RU

16. Mandelbrot B.B. The fractal geometry of nature. New York: Freeman, 1982, $468 \mathrm{p}$.

17. Mierziak J., Kostyn K., Kulma A. Flavonoids as Important Molecules of Plant Interactions with the Environment // Molecules, 2014, vol. 19, no. 10, pp. 16240-16265. https://doi.org/10.3390/molecules 191016240

18. McGill B.J. Towards a unification on unified theories of biodiversity // Ecology Letters, 2010, vol. 13, no. 5, pp. 627-642. https://doi.org/10.1111/j.14610248.2010.01449.x

19. Petrussa E., Braidot E., Zancani M., Peresson C., Bartolini A., Patui S., Vianello A. Plant flavonoids-biosynthesis, transport and involvement in stress responses // Int. J. Mol. Sci, 2013, vol. 14, no. 7, pp. 14950-14973. https://doi.org/10.3390/ ijms 140714950

20. Розенберг Г.С. Модели в фитоценологии. М.: Наука, 1984. 240 с.

21. Розенберг Г.С. Введение в теоретическую экологию / В 2-х т.; Изд. 2-е, исправленное и дополненное. Тольятти: Кассандра, 2013. Т. 1. 565 с. Т. 2. $445 \mathrm{c}$.

22. Tilman D. Niche tradeoffs, neutrality, and community structure: A stochastic theory of resource competition, invasion and community assembly // Presiding of the National Academy of Science (PNAS), 2004, vol. 101, no. 30, pp. 10854-10861. https://doi.org/10.1073/pnas.0403458101

23. Усманов И.Ю., Щербаков А.В., Мавлетова М.В., Юмагулова Э.Р., Иванов В.Б., Александрова В.В. Пульсирующая многомерная экологическая ниша растений: расширение объема понятия // Известия Самарского научного центра Российской академии наук. 2016. Т. 18, № 2-2. С. 525-529. http:// www.ssc.smr.ru/media/journals/izvestia/2016/2016_2_525_529.pdf

24. Усманов И.Ю., Юмагулова Э.Р., Иванов В.Б., Коркина Е.А., Щербаков А.В., Иванов Н.А., Рябуха А.В. Адаптация экосистем Среднего Приобья в зоне нефтедобычи: иерархия и длительность процессов // Вестник Ниж- 
невартовского государственного университета. 2016. № 2. C. 87-94. https:// vestnik.nvsu.ru/2311-1402/article/view/49497

25. Усманов И.Ю., Иванов В.Б., Иванов Н.А. Самовосстановление экосистем Среднего Приобья при антропогенных воздействиях нефтедобывающего комплекса // Экологические проблемы бассейнов крупных рек - 6: Материалы международной конференции. Тольятти: Анна, 2018. С. 303-305.

26. Усманов И.Ю., Овечкина Е.С., Юмагулова Э.Р., Иванов В.Б., Щербаков А.В., Шаяхметова Р.И. Проблемы самовосстановления экосистем Среднего Приобья при антропогенных воздействиях нефтедобывающего комплекса // Вестник Нижневартовского государственного университета. 2015. № 1. C. 79-86. https://vestnik.nvsu.ru/2311-1402/article/view/49407

27. Усманов И.Ю., Щербаков А.В., Иванов В.Б., Юмагулова Э.Р. Фрактальный анализ системы биосинтеза флавоноидов // IX Съезд общества физиологов растений России «Физиология растений - основа создания растений будущего». Тезисы докладов. Казань, 2019. С. 446.

28. Усманов И.Ю., Щербаков А.В., Юмагулова Э.Р., Иванов В.Б. Признаки нейтральности при формировании спектров флавоноидов в природных ценопопуляциях // Экология и эволюция: новые горизонты. Материалы Международного симпозиума, посвященного 100-летию академика С.С. Шварца. Институт экологии растений и животных УрО РАН, 2019. С. 288-289.

29. Усманов И.Ю., Юмагулова Э.Р., Александрова В.В., Гончар И.Г., Щербаков А.В., Иванов В.Б. Комплексы флавоноидов Chamaedaphne Calyculata (L.) Moench олиготрофных болот Средней Оби // Вестник Нижневартовского государственного университета. 2019. № 2. С. 59-71. https://doi. org/10.36906/2311-4444/19-2/08

30. Usmanov I.Yu., Yumagulova E.R., Ivanov V.B., Aleksandrova V.V., Ivanov N.A., Schaichmetova R.I., Scherbakov A.V., Mavletova-Chistuakova M.V. Physiological barriers for adventitious species invasion in oligotroph ecosystems of the middle Ob Area // Vegetos: An International Journal of Plant Research, 2017, vol. 30, no. 4, pp. 81-85. https://doi.org/10.5958/2229-4473.2017.00195.1

31. Usmanov I., Ivanov V., Shcherbakov A. System for ecological regulation of the biosynthesis of flavonoids as a strange attractor // Modern Phytomorphology. 2020. Vol. 14. pp. 77-84. https://www.phytomorphology. com/articles/system-for-ecological-regulation-of-the-biosynthesis-of-flavonoids-as-a-strange-attractor.pdf

32. Usmanov I.Yu., Yumagulova E.R., Aleksandrova V.V., Ivanov S.P., Shcherbakov A.V., Ivanov V.B., Gonchar I.G. Fractal analysis of flavonoids in complex chemical compositions in extracts of Chamaedaphne calyculata (L.) Moench (ERICA- 
CEAE) In oligotrophic swamps of Western Siberia // Modern Phytomorphology, 2019, Vol. 13, pp. 35-40. https://nvsu.ru/ru/scientific_laboratories/396/55.pdf

33. Usmanov I.Yu., Ivanov V.B., Abdrakhimova G.S., Shcherbakov A.V., Yumagulova E.R., Aleksandrova V.V. Fractal Analysis of Flavonoids in Composition HPLC-Fingerprint Extracts of Oxycoccus palustris Pers. (ERICACEAE) in Oligotrophic Swamps of Western Siberia // International Journal of Advanced Biotechnology and Research, 2019, vol. 10, no. 2, pp. 369-376. https://www. bipublication.com/files/ijabr2019252Usmanov.pdf

34. Usmanov I.Yu., Yumagulova E.R., Ovechkina E.S., Ivanov V.B., Aleksandrova V.V., Ivanov N.A., Shcherbakov A.B. Fractal Analysis of Morpho-Physiological Parameters of Oxycoccus Palustris Pers in Oligotrophic Swamps of Western Siberia // Vegetos: An International Journal of Plant Research, 2016, vol. 29, no. 1, pp. 1-3. https://doi.org/10.5958/2229-4473.2016.00002.1

35. Usmanov I., Shcherbakov A., Ivanov V., Ivanov S., Gonchar I. Use of fractal analysis principles when describing flavonoids variety of the south transurals plants // Modern Phytomorphology, 2020, vol. 14, pp. 13-19. https://doi. org/10.5281/zenodo.4453866

36. Usmanov I.Yu., Scherbakov A.V., Ivanov V.B., Ivanova A.V. Fractal Nature of Multidimensional Ecological Niche: Real Habitats in South Trans-Urals / S.G. Maximova, R.I. Raikin, M.M. Silantyeva, \& A.A. Chibilyov (Eds.) // Advances in Natural, Human-Made, and Coupled Human-Natural Systems. Cham, Switzerland: Springer, 2021.

37. Harborne J.B. The flavonoids: advances in research since. Springer, 1980. https://www.springer.com/gp/book/9780412287701

38. Hubbell S.P. Neutral theory and the evolution of ecological equivalence // Ecology, 2006, vol. 87, no. 6, pp. 1387-1398. https://doi. org/10.1890/0012-9658(2006)87[1387:ntateo]2.0.co;2

39. Scherbakov A.V., Ivanov V.B., Ivanova A.V., Usmanov I.Y. The Equifinal Achievement of the Total Antioxidant Activity of Flavonoids by Plants in Various Habitats // IOP Conference Series: Earth and Environmental Science, 2021, vol. 670 (1). https://doi.org/10.1088/1755-1315/670/1/012018

\section{ДАННЫЕ ОБ АВТОРАХ}

Иванов Вячеслав Борисович, кандидат педагогических наук, доцент ФГБОУ ВО «Нижневартовский государственный университет» ул. Ленина, 56, г. Нижневартовск, Ханты-Мансийский автономный округ, 628605, Российская Федерация karatazh@mail.ru 
Щербаков Аркадий Владимирович, кандидат биологических наук, доцент

ООО «Институт тканевой и генетической инженерии» ул. Менделеева, 9, г. Уфа, 450047, Российская Федераиция

\section{DATA ABOUT THE AUTHORS}

Vyacheslav B. Ivanov, Candidate of Pedagogical Sciences, Associate Professor Nizhnevartovsk State University

56, Lenin Str., Nizhnevartovsk, Khanty-Mansiysk Autonomous Area-Yugra, 628605, Russian Federation

karatazh@mail.ru

ORCID: 0000-0001-6617-4634

Scopus Author ID: 56282339200

ResearcherID: $A A$-5511-2020

Arkady V. Shcherbakov, Candidate of Biological Sciences, Associate Professor

Institute of Genetic and Tissue Engineering 9, Mendeleev Str., Ufa, 450047, Russian Federation

humanist314@rambler.ru

ORCID: 0000-0002-7089-6100 